\title{
Effect of protein nutrition on the mRNA content of insulin-like growth factor-binding protein-1 in liver and kidney of rats
}

\author{
BY ASAKO TAKENAKA, MITSUKO HIROSAWA, MASAMICHI MORI, \\ SANAE YAMADA, YUTAKA MIURA, HISANORI KATO, \\ SHIN-ICHIRO TAKAHASHI AND TADASHI NOGUCHI* \\ Department of Agricultural Chemistry, Faculty of Agriculture, The University of Tokyo, Bunkyo-ku, \\ Tokyo 113, Japan
}

(Received 12 August 1991-Accepted 7 January 1992)

\begin{abstract}
Effect of quantity and nutritional quality of dietary proteins on the content of mRNA of insulin-like growth factor-binding protein-1 (IGFBP-1) was studied in rat liver and kidney. IGFBP-1 mRNA content per unit RNA increased in liver and kidney of rats fed on a protein-free diet and in those of fasted rats compared with that in the rats fed on a casein diet. When rats were given a gluten diet for $7 \mathrm{~d}$, IGFBP1 mRNA content in liver did not change significantly but that in kidney increased considerably compared with that in those organs of the rats fed on the casein diet. Because IGFBP-1 mRNA has been demonstrated both in liver parenchymal and non-parenchymal cells (Takenaka $e t$ al. 1991), the effect of the protein-free diet on these two types of cells has been studied. An increase in IGFBP-1 mRNA content under protein deprivation was observed in both liver parenchymal and non-parenchymal cells, suggesting that these two types of cells are regulated in a similar mode as far as IGFBP-1 mRNA content is concerned. The physiological and nutritional significance of the previously stated results on protein anabolism are discussed when considered together with our previous observations on the plasma concentrations of IGF-1 (Takahashi et al. 1990) and IGFBP (Umezawa et al. 1991) and insulin-like growth factor-1 mRNA content in liver (Miura et al. 1991).
\end{abstract}

Insulin-like growth factor-1: Dietary protein: Protein deficiency: IGF-binding protein-1 mRNA: Rat

Insulin-like growth factor (IGF)-1 is a hormone the plasma concentration of which is regulated by quantity and nutritional quality of dietary proteins (for detailed discussion with citations, see Takahashi et al. 1990 and for extensive review, see Clemmons \& Underwood, 1991). In a previous paper, the plasma concentration of this hormone was determined by two methods (Takahashi et al. 1990): one was to measure the concentration immunologically without any pretreatments (the value obtained by this method was referred to as irIGF-1), and the other was after treatment of the plasma with an acid-ethanol mixture (this value was referred to as tIGF-1; Takahashi et al. 1990). The latter treatment has been suggested to dissociate IGF-1 from the IGF-1-IGF-binding protein (IGFBP) complexes (Daughaday et al. 1980). We have found that the ratio irIGF1 : tIGF-1 increased significantly under good nutritional conditions, and assumed that this ratio reflected the distribution of IGF-1 to IGF-1-IGFBP-3 complex under specific nutritional conditions for the following reasons: (1) the immunoreactivity of IGF-1 in IGFBP-3 fraction (fraction A of Takahashi et al. 1990) was higher than that in the fraction rich in IGFBP-1 (fraction C of Takahashi et al. 1990), (2) under good nutritional conditions, the amount of IGF-1 complexed to IGFBP-3 (or IGF-1 bound to the large binding protein) increases and that complexed to IGFBP-1 (or IGF-1 bound to the small 
Table 1. The composition of the experimental diets $(\mathrm{g} / \mathrm{kg})$

\begin{tabular}{lccc}
\hline \hline & Protein-free & Gluten & Casein \\
\hline$\beta$-Maize starch & 800 & 650 & 657 \\
Gluten* & & 150 & 141 \\
Casein & & & 2 \\
Methionine & & & \\
\hline
\end{tabular}

In addition to these components, all diets contained $(\mathrm{g} / \mathrm{kg})$ : soya-bean oil 50 , cellulose 100 , mineral mixture 40 and vitamin mixture 10. The mineral and vitamin mixtures (obtained from Nihon Nosan Co., Tokyo) were prepared according to the American Institute of Nutrition (1977).

*Crude protein (nitrogen $\times 6.25$ ) $800 \mathrm{~g} / \mathrm{kg}$.

$\dagger$ Crude protein $840 \mathrm{~g} / \mathrm{kg}$.

binding protein) decreases (Takahashi et al. 1990), (3) plasma IGFBP-3 concentration increased significantly under good nutritional conditions, but IGFBP-1 did not (Umezawa et al. 1991).

These results suggested that synthesis of IGFBP is greatly affected by nutritional conditions of animals. In this context we investigated the effect of protein deprivation on mRNA content of IGFBP. In the present paper the results for IGFBP-1 in liver and kidney of rats have been reported because the mRNA was found only in these two organs (Takenaka et al. 1991). The changes in the mRNA content of IGFBP-3 and other IGFBP will be reported in separate papers.

\section{MATERIALS AND METHODS}

\section{Animals}

Male Wistar rats of initial body weight $120 \mathrm{~g}$ were purchased from SLC Japan (Hamamatsu, Japan) and used throughout the experiments. The rats were kept in a room maintained at $22 \pm 1^{\circ}$ with $12 \mathrm{~h}$ light-dark cycle (light period from 08.00 to 20.00 hours and dark period from 20.00 to 08.00 hours). The rats were fed on a casein diet from 10.00 to 18.00 hours for $3 \mathrm{~d}$ before they were given the experimental diets. The experimental diets were given by the same time schedule for $7 \mathrm{~d}$. At 11.30 hours on day 8 they were killed by decapitation under pentobarbital anaesthesia. The composition of the experimental diets is shown in Table 1.

In the fasting experiment rats were deprived of food (the casein diet) for $48 \mathrm{~h}$ from 18.00 hours on day 6 . In this case, the fasted rats were killed at 18.00 hours on day 8 .

In the paired feeding experiment the food intake of the rats fed on the protein-free diet was measured and the same amount of the casein or gluten diet was fed to the paired rats on the next day. The rats were paired to each of the protein-deprived rats. Therefore, variations in food intake were also reproduced in the paired groups. Because of this feeding programme the rats of the paired groups were killed $1 \mathrm{~d}$ later than the protein-deprived rats. The rats of the paired groups ate all the offered feed.

\section{Synthesis of $c D N A$ of IGFBP-I}

Rat IGFBP-1 cDNA which corresponds to the nucleotides 123-848 of the cDNA clone described by Murphy et al. (1990) was amplified by a reverse transcriptase-polymerase chain reaction (RT-PCR) technique. Primer oligonucleotides were synthesized with an Applied Biosystems model 391 synthesizer and purified by polyacrylamide-gel electro- 
phoresis. The two PCR primers used to identify IGFBP-1 were a sense primer of $23 \mathrm{mer}$ (5'GGTACCGTTCCTGATCCTCCTGT3') and an anti-sense primer of $22 \mathrm{mer}$ ( $5^{\prime}$ TCTAGATCTTCTTCCCACTCCA3'). Kpn I and $X b a I$ sites were included in the sense and anti-sense primers to allow the subcloning of the PCR products into M13 sequencing vector (Boehringer, Mannheim, Germany).

The PCR reactions were performed with Taq polymerase (Perkin Elmer Cetus, Norwalk, CT, USA) according to the instructions supplied. The first cycle consisted of the denaturation step at $94^{\circ}$ for $5 \mathrm{~min}$, the annealing step at $50^{\circ}$ for $1 \mathrm{~min}$, and the extension step at $72^{\circ}$ for $1 \mathrm{~min}$. The following twenty-six cycles consisted of $94^{\circ}$ for $1 \mathrm{~min}, 50^{\circ}$ for $2 \mathrm{~min}$ and $72^{\circ}$ for $1 \mathrm{~min}$ for each step. The final extension step of the cycle was extended to $10 \mathrm{~min}$. The template cDNA was synthesized from $2.5 \mu \mathrm{g}$ poly (A) ${ }^{+}$RNA which was obtained from primary cultured rat hepatocytes as follows. The hepatocytes were prepared as described previously (Takenaka et al. 1989) and inoculated in $60 \mathrm{~mm}$ collagen-coated dishes (Corning, Corning, NY, USA) at a cell density of $2 \times 10^{6}$ cells/dish. The cells were cultured for $24 \mathrm{~h}$ in Williams' $\mathrm{E}$ medium (Flow Laboratories, McLean, VA, USA) supplemented with $100 \mathrm{ml}$ calf serum (Gibco, Grand Island, NY, USA)/1, $10^{-8} \mathrm{M}$-insulin and $10^{-6} \mathrm{M}$-dexamethasone (both Sigma, St Louis, MO, USA) in a $\mathrm{CO}_{2}$ incubator. After this incubation, the medium was changed to Williams' E medium supplemented only with $10^{-6} \mathrm{M}$-dexamethasone. The cells were incubated in this medium for a further $24 \mathrm{~h}$. Then, the cells were harvested and the total RNA was prepared according to Puissant \& Houdebine (1990). The poly (A) ${ }^{+}$RNA was obtained using Oligo (dT)-Latex (Oligotex ${ }^{(-}$ dT 30; Japan Roche, Tokyo, Japan). From this poly (A) ${ }^{+}$RNA, cDNA was synthesized (according to the method of synthesis of the first strand cDNA) using a cDNA Synthesis System Plus (Amersham International Plc, Amersham, Bucks, UK). One-tenth the amount of this cDNA product was used for each PCR reaction. After the reaction cycle the PCR reaction mixture was extracted with chloroform-isoamyl alcohol and the cDNA in the water phase was further purified by agarose gel electrophoresis. The final product was labelled with $\left[\alpha-{ }^{32} \mathrm{P}\right] \mathrm{dCTP}$ (Amersham International Plc, Amersham, Bucks, UK; $3000 \mathrm{Ci} / \mathrm{mmol}$ ) using a Takara Nick Translation Kit (Takara, Kyoto, Japan). The deoxyribonucleotide sequence of the PCR-amplified cDNA was confirmed by the doublestranded dideoxy-chain termination method employing Sequenase Version 2.0 (United States Biochemical Corporation, Cleveland, OH, USA).

\section{Northern blot analysis}

Just after decapitation, liver and kidney were quickly excised, frozen in liquid $\mathrm{N}_{2}$, and stored at $-80^{\circ}$ until use. Total RNA was prepared from these frozen tissues as described previously. The method of Northern blot analysis was the same as that reported previously (Miura et al. 1991) except that the nitrocellulose membrane was replaced with a type (BAS 85 ) obtained from Schleicher \& Schull (Dassel, Germany) in the present investigations. The molecular size of IGFBP-1 mRNA was certified to be $1.6 \mathrm{~kb}$ as reported by others (Murphy et al. 1990) using an RNA ladder (Gibco BRL, Gaithersburg, MD, USA). This size was confirmed at every run from the relative position of the mRNA to $18 \mathrm{~S}$ rRNA. The amount of the total RNA specified for each experiment was used for agarose-formaldehyde gel electrophoresis. The amount of applied RNA was confirmed by staining with ethidium bromide (Rosen et al. 1990). The results of the autoradiography were quantified using a Fujix Bas 2000 system (Fuji Film Co., Kanagawa, Japan) or employing a densitometer (dual-wavelength flying-spot scanner CS-9000; Shimadzu, Kyoto, Japan). 
Table 2. Final body weight and daily food intake in rats fed on various protein sources (Values are means with their standard errors for five rats)

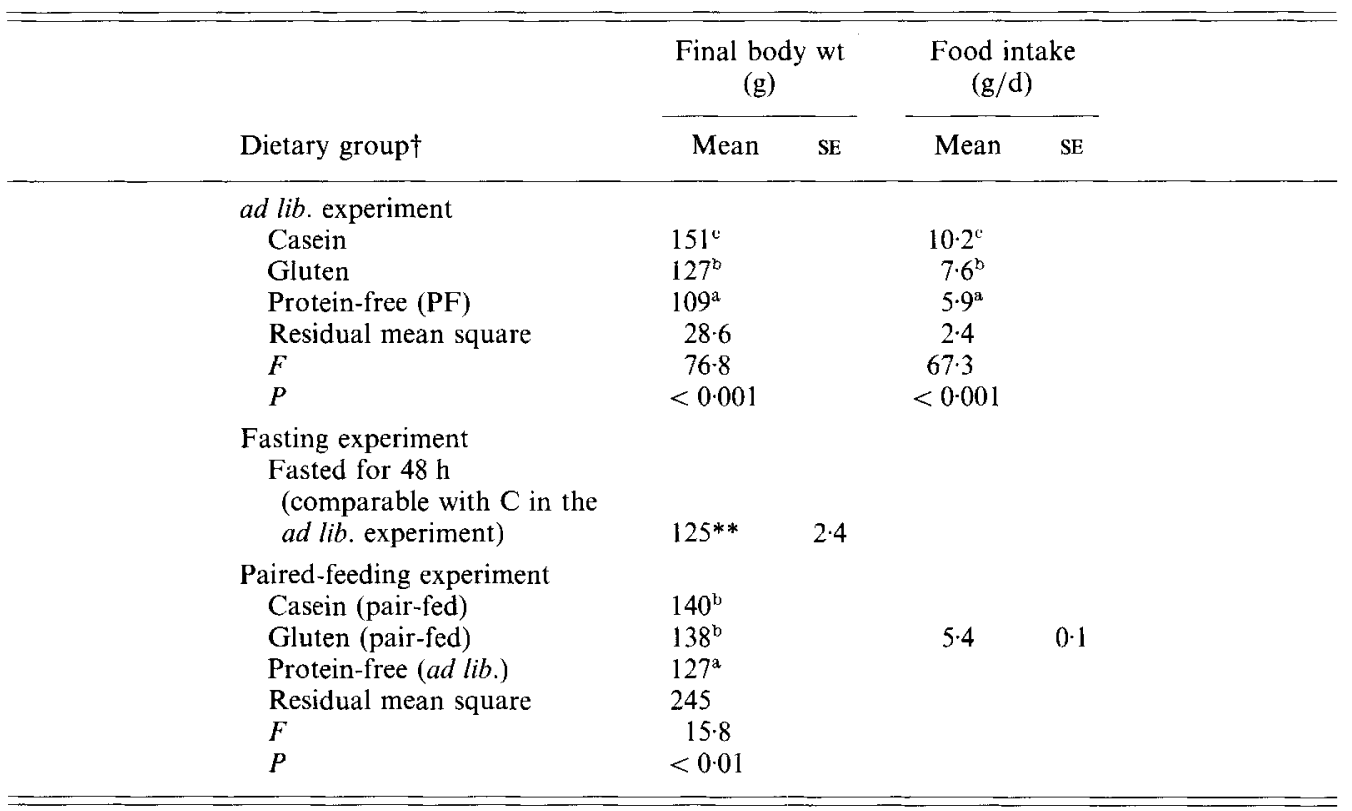

a.b.e Values with unlike superscript letters were significantly different $(P<0.05$ or less) by Tukey's $Q$ test (Snedecor \& Cochran, 1967).

Mean value was significantly different from that of group $\mathrm{C}$ in the ad lib. experiment: $* * P<0.01$.

$\uparrow$ For details of diets, see Table 1.

\section{Dot blot hybridization}

The total RNA of $20 \mu \mathrm{g}$ which was prepared for Northern blot analysis was used in dot blot analyses. The RNA was dotted onto the previously-mentioned nitrocellulose membrane using MilliBlot ${ }^{\infty}$-Systems (Millipore, MA, USA) and baked at $80^{\circ}$ for $2 \mathrm{~h}$. The subsequent procedure was the same as that of Northern blot analysis.

Preparation of parenchymal and non-parenchymal cells

Parenchymal and non-parenchymal cells were prepared as described previously (Takenaka et al. 1991). Total RNA was prepared from these cells as described above and used for Northern blot analysis.

\section{Statistical analysis}

The results were analysed statistically by analysis of variance (one-way classification) and Tukey's Q test (Snedecor \& Cochran, 1967). When the results were obtained as an all-ornothing type (Figs 4 and 5) they were not analysed statistically.

\section{RESULTS}

Table 2 shows the changes in body weight and food intake of the rats employed in the present experiments. Feeding the protein-deficient diet caused a decrease in food intake.

Fig. 1 shows the results of Northern blot analysis of IGFBP-1 in liver and kidney. The results show that only one molecular species of IGFBP-1 mRNA was present in liver and kidney. Furthermore, the IGFBP-1 mRNA contents (per unit RNA) in liver and kidney 

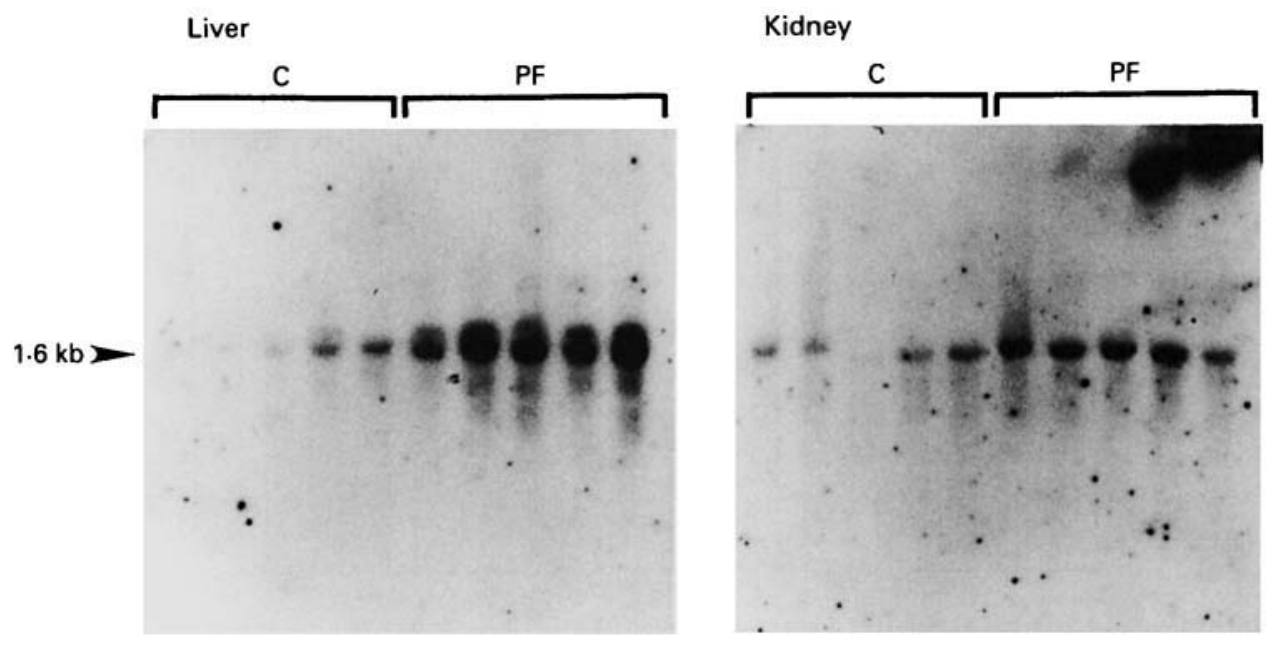

Fig. 1. Northern blot analysis of insulin-like growth factor-binding protein (IGFBP)-1 messenger RNA in liver and kidney of rats and the effects of protein deprivation on its contents. RNA were extracted from liver and kidney of rats fed on a casein (C) or a protein-free (PF) diet for $7 \mathrm{~d}$. The IGFBP-1 mRNA content in the RNA was determined by Northern blot hybridization technique. A $50 \mu \mathrm{g}$ portion of total RNA was applied to each lane. For details of procedures, see pp. $74-75$.
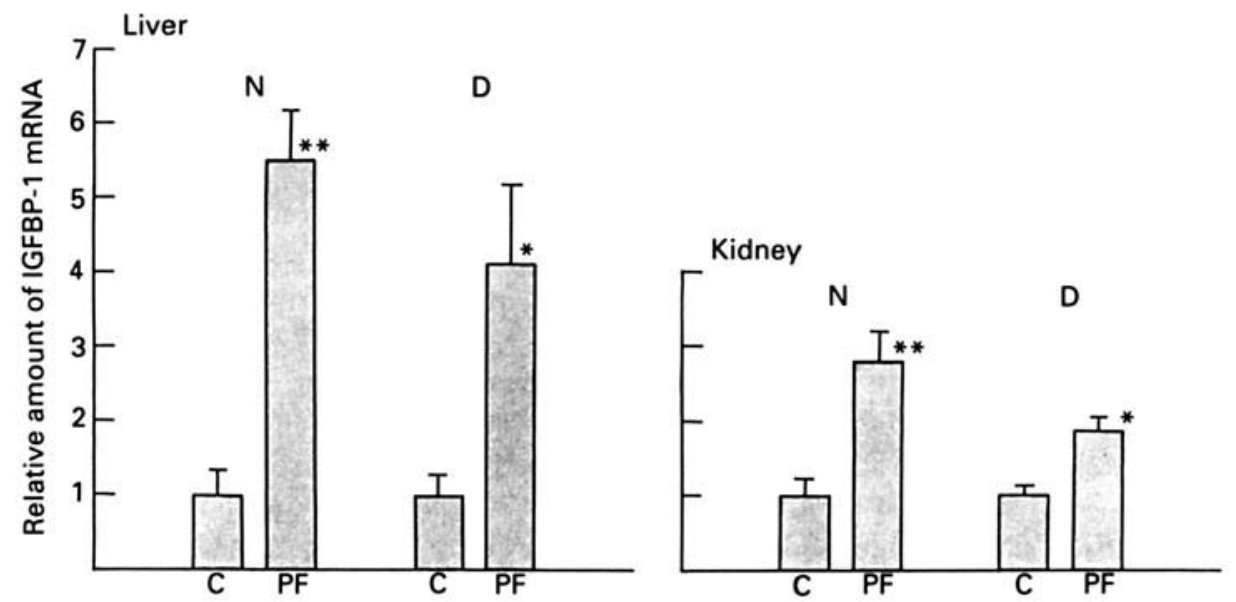

Fig. 2. The effect of protein deprivation on insulin-like growth factor-binding protein (IGFBP)-1 mRNA content in liver and kidney of rats. The results of Northern blot analyses shown in Fig. $1(N)$ and dot blot hybridization analyses (D) of IGFBP-1 mRNA content in liver or kidney of rats given the protein-free (PF) diet were determined quantitatively employing a Fujix Bas 2000 system (Fuji Film Co.; Northern blot analysis) or a densitometer (dot blot analysis). The values were standardized by dividing the observed radioactivity (the arbitrary unit of absorbance in densitometry or the specified signal intensity in Bas 2000 system) by the mean value of the casein (C) group and are based on a mean value for the C group of 1 . A $50 \mu \mathrm{g}$ portion of total RNA was applied to each lane in the case of Northern blot analysis and $20 \mu \mathrm{g}$ total RNA was dotted on the membrane in the case of dot blot analysis. Values are means with their standard errors represented by vertical bars. Mean values were significantly different from those of $\mathrm{C}$ group: ${ }^{*} P<0.05,{ }^{* *} P<0.01$. For details of procedures, see pp. 74-76.

greatly increased under protein deprivation. Because the Northern blot analysis showed that mRNA of IGFBP-1 gave a single band, the mRNA content was also quantified by dot blot hybridization. Fig. 2 shows the results of dot blot hybridization together with the results of the quantitative analysis of the Northern blot hybridization. The IGFBP-1 mRNA content increased more than 4-fold in the liver of protein-deprived rats. Both 

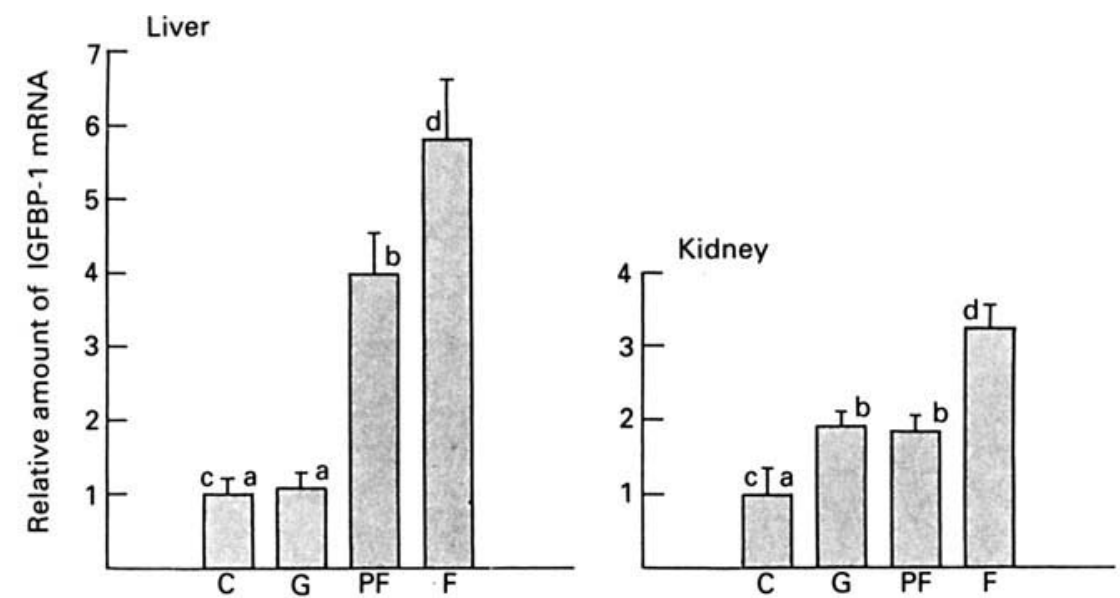

Fig. 3. Effect of feeding a gluten $(G)$ diet, protein-free $(P F)$ diet and fasting $(F)$ on insulin-like growth factorbinding protein (IGFBP)-1 mRNA content of liver and kidney (dot blot analysis). RNA was extracted from liver and kidney of rats fed on the experimental diets for $7 \mathrm{~d}$. IGFBP-1 mRNA content in the RNA was determined by dot blot analysis ( $20 \mu \mathrm{g}$ total RNA was dotted on the membrane). Values are means with their standard errors represented by vertical bars. The differences between casein (C) G and PF groups and the difference between $\mathrm{C}$ and $\mathrm{F}$ groups were analysed separately. $a, b, c, d$ Means with unlike superscript letters ( $a, b$, for $\mathrm{C}, \mathrm{G}$ and $\mathrm{PF}$ groups; $\mathrm{c}, \mathrm{d}$ for $\mathrm{C}$ and $\mathrm{F}$ groups) were statistically significant. For details of procedures, see pp. $74-76$.

results coincided well. Other mRNA, for albumin and $\beta$-actin, remained in approximately constant proportion on the total RNA on the different dietary treatments (results not shown), demonstrating the specificity of the response in IGFBP-1 mRNA content.

Fig. 3 shows the effect of fasting on the content of IGFBP-1 mRNA in liver and kidney elucidated by dot blot analysis. A significant increase in mRNA content was observed in fasted rats. These results are consistent with those of Ooi et al. (1990) and Murphy et al. $(1990,1991)$. The relative increase in IGFBP-1 mRNA in the liver of rats fed on the proteinfree diet was similar to that observed in the fasted rats. This means that supplementation of energy (starch) in the absence of a protein source did not improve the nutritional status as far as it is judged by IGFBP-1 mRNA content in liver. Fig. 3 also shows the results of dot blot analysis of the liver and kidney of rats fed on the casein and gluten diets. There was a significant growth retardation in the rats fed on the gluten diet (Table 1). However, the effect of the gluten diet on IGFBP-1 mRNA content in liver of the rats was not as prominent. This means that feeding a marginal essential amino acid-deficient diet does not affect significantly the IGFBP-1 mRNA content in liver as far as the present experimental conditions are concerned. However, kidney responded to the gluten diet differently. The IGFBP-1 mRNA content in the kidney of rats fed on the gluten diet increased to a level close to that of the protein-deprived rats. The reason for the difference in the response to the gluten diet between liver and kidney is unclear.

Fig. 4 shows a typical Northern blot of RNA extracted from the livers of rats fed on the casein, gluten and protein-free diets. Fig. 4(A) shows the findings for ad lib.-fed rats, and Fig. 4(B) shows those of rats pair-fed to those fed on the protein-free diet. A marked increase in IGFBP-1 mRNA in the liver of rats fed on the protein-free diet was observed in both ad lib.-fed and pair-fed experiments. This means that the effect of protein-free diet on liver IGFBP-1 mRNA is primarily due to the effect of protein deficiency and not due to the decreased food intake.

Fig. 5 shows the effect of protein deprivation on the mRNA content of parenchymal and 


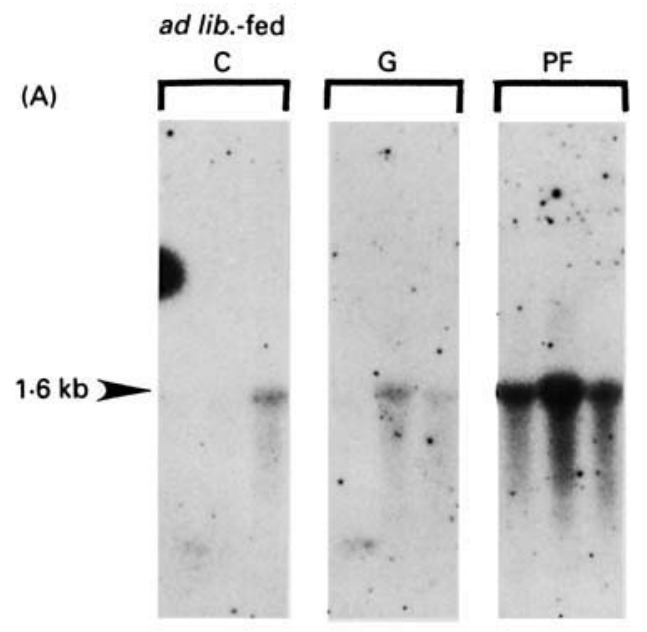

(B)

\section{Pair-fed}
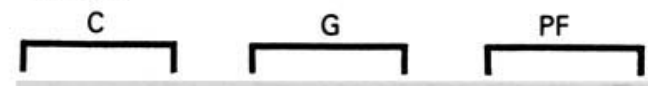

$1.6 \mathrm{~kb}$

Fig. 4. Effect of ad lib.-feeding and paired-feeding of the gluten $(\mathrm{G})$ or casein $(\mathrm{C})$ diet on the insulin-like growth factor-binding protein (IGFBP)-1 mRNA content in liver of rats. In the pair-fed experiment, the feed intake of the rats fed on the protein-free (PF) diet was determined and the same amount of the $C$ or $G$ diet was fed to other rats on the next day. RNA was extracted from the liver and the content of IGFBP-1 mRNA was determined by Northern blot hybridization technique. A $20 \mu \mathrm{g}$ portion of total RNA was applied to each lane. Typical results for three rats are shown. For details of procedures, see pp. 74-75.

non-parenchymal cells of rat liver. The IGFBP-1 mRNA content increased in both parenchymal and non-parenchymal cells of rat liver under protein deprivation. This means that both parenchymal and non-parenchymal cells are affected by protein deficiency. The apparent variation in mRNA concentrations shown in Figs 4 and 5 is typical of observations when many changes are induced. Technical uncertainties can be eliminated since such variability was not observed when the membranes were reprobed for other, noninduced mRNA, i.e. IGF-1, IGFBP-3 and $\beta$-actin (values not shown). 


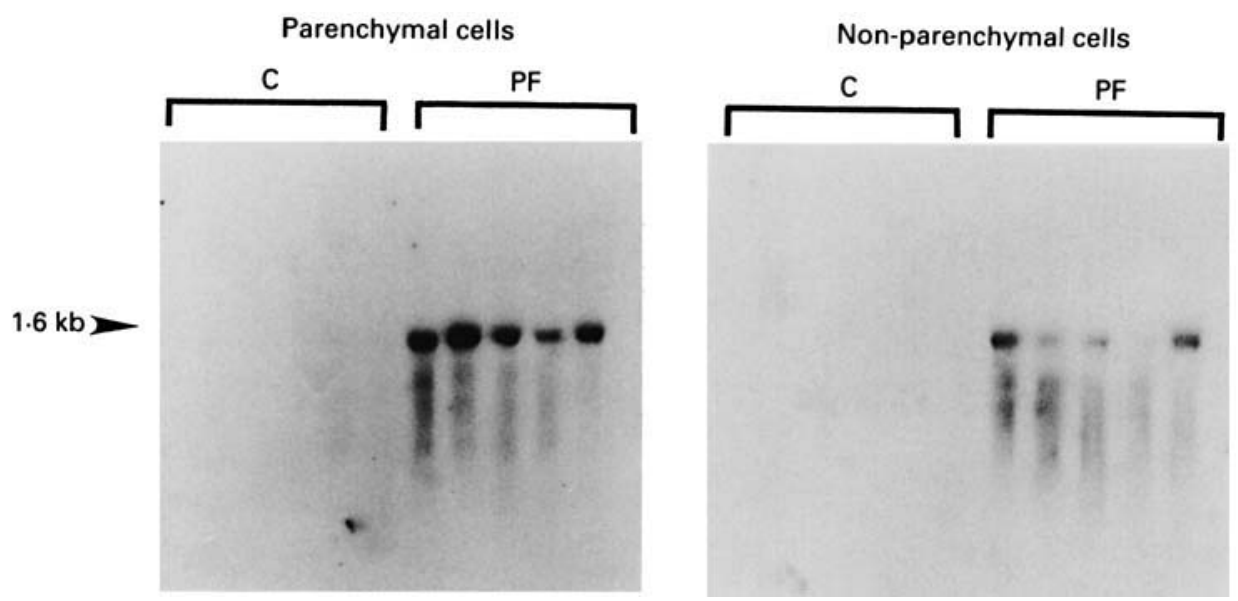

Fig. 5. The effect of protein deprivation on the insulin-like growth factor-binding protein (IGFBP)-1 mRNA content of parenchymal and non-parenchymal cells of rat liver. Parenchymal and non-parenchymal cells of liver from protein-deprived (PF) rats and the control rats fed on the casein (C) diet were prepared and IGFBP-1 mRNA contents of those cells were determined by Northern blot analysis. A $50 \mu \mathrm{g}$ portion of total RNA was applied to each lane. For details of procedures, see pp. 74-76.

\section{DISCUSSION}

Plasma protein concentration generally decreases under protein deprivation. IGF-1 belongs to this type of protein, decreasing its concentration under protein deficiency (Takahashi et al. 1990). Among IGFBP, the plasma concentration of IGFBP-3 also decreases in rats fed on a protein-free diet (Umezawa et al. 1991). In contrast, the concentration of IGFBP-1 increases during fasting (Baxter \& Cowell, 1987; Busby et al. 1988; Cotterill et al. 1988) or does not change significantly (or increases slightly) under protein deprivation (Umezawa et al. 1991). These findings suggest that the synthesis or secretion of IGFBP-1 is differently regulated from that of IGFBP-3 or other proteins in general.

Tissue polyadenylated RNA content (most possibly reflecting the total mRNA content) generally decreases (R. Funabiki, personal communication) and abundant mRNA, e.g. serum albumin mRNA and $\beta$-actin mRNA, also decrease in protein-deprived animals (Sakuma et al. 1987; Straus \& Takemoto, 1990) with a concomitant decrease in the total RNA (primarily rRNA) under poor nutritional conditions (Waterlow et al. 1978). The present results showed that IGFBP-1 mRNA content per unit amount of total RNA in both liver and kidney increased greatly in rats fed on the protein-deficient diet compared with that of rats fed on the casein diet. This increase in IGFBP-1 mRNA was observed as the relative increase to total RNA. However, it must also be an absolute increase because the total RNA is unlikely to decrease to less than one-quarter the original level (Waterlow et al. 1978). However, this significant increase in IGFBP-1 mRNA under protein-deprived conditions must be exceptional among mRNA species.

The increase in IGFBP-1 mRNA in liver and kidney reported here probably explains the unchanged or slightly increased concentration of IGFBP-1 in the plasma of rats fed on the protein-free diet (Umezawa et al. 1991). The maintenance of plasma IGFBP-1 under protein-free conditions may be attributable to several phenomena including alterations in rates of translation or changes in the biological half-life of the circulating protein. The relative increase in mRNA for the protein does indicate another possible mechanism, however, with the increased message being associated either with increased rates of transcription or improved mRNA stability; both systems would provide more mRNA for translation. 
Previously it was demonstrated that IGFBP-1 or IGF-1 mRNA are localized in both parenchymal and non-parenchymal cells in rat liver (Takenaka et al. 1991). On the contrary, IGFBP-3 mRNA was exclusively localized in liver non-parenchymal cells (Takenaka et al. 1991). This means that both types of cells play different roles in the production of IGF-1 or IGFBP. The present findings suggested that IGFBP-1 mRNA in both liver parenchymal and non-parenchymal cells are regulated by nutritional factors through a similar mechanism in which a similar type of transcription factor may be involved.

As regards the effect of nutritional quality of dietary proteins, the decrease in IGF-1 mRNA content in the liver of rats fed on the gluten diet was similar to that in the liver of rats fed on the protein-free diet. In the case of IGFBP-1, the effect of feeding on a gluten diet on the mRNA content in liver was not as significant as that of feeding on the proteinfree diet. Namely, the effect of the gluten diet was similar to that of the protein-free diet in the case of liver IGF-1 mRNA but was similar to that of casein in the case of liver IGFBP-1 mRNA. On the other hand, kidney responded to the gluten diet in a different way from that of liver. In the kidney of rats fed on the gluten diet, IGFBP-1 mRNA content was similar to that found in protein-deprived rats. The reason for these observations remains to be elucidated. The effect of the balance of essential amino acids on IGF-1 or IGFBP-1 mRNA in liver and kidney should be examined carefully.

There are some suggestions concerning the physiological significance of IGFBP (for review, see Baxter, 1988, 1991; Baxter \& Martin, 1989), although no agreed concept is available. For example, some reports have shown that the purified IGFBP-1 depressed the stimulation of DNA synthesis induced by IGF-1 (Knauer \& Smith, 1980; Ritvos et al. 1988), whereas controversial results have also been reported (Elgin et al. 1987; DeMellow \& Baxter, 1988; Busby et al. 1989). From the nutritional point of view, our following observations on protein deprivation: (1) a significant decrease in plasma IGF-1 and IGFBP-3 concentration, (2) relatively stable plasma concentration of IGFBP-1, (3) a prominent decrease in liver IGF-1 mRNA, (4) a great increase in liver and kidney IGFBP-1 mRNA, seem to support our hypothesis for the role of IGF-1 and IGFBP in protein metabolism. Namely, forming the IGFBP-1-IGF-1 complex, which is supposed to repress the activity of IGF-1, protects IGF-1 from degradation by tissues, bringing about the elongation of the half-life of this hormone in plasma. By these mechanisms IGF-1 is protected in plasma without showing any activity under such physiological conditions which need to depress the activity of IGF-1. This protected IGF-1 may form a complex with IGFBP-3 and show its biological activity later by the mechanism proposed by Kaufmann et al. (1978) when the nutritional status is recovered. This assumption is very hypothetical and remains to be proved.

In summary, protein deprivation or malnutrition caused an increase in IGFBP-1 mRNA content in liver and kidney. We conclude that the previously described observations on IGFBP-1 mRNA add further evidence to our previous speculation that IGF-1 and IGFBP play important roles in body protein metabolism.

\section{REFERENCES}

American Institute of Nutrition (1977). Report of the AIN Ad Hoc Committee on Standards for Nutritional Studies. Journal of Nutrition 107, 1340-1348.

Baxter, R. C. (1988). The insulin-like growth factors and their binding proteins. Comparative Biochemistry and Physiology 91B, 229-235.

Baxter, R. C. (1991). Physiological roles of IGF binding proteins. In Modern Concepts of Insulin-Like Growth Factors, pp. 371-380 [E. M. Spencer, editor]. New York, Amsterdam, London, Tokyo: Elsevier.

Baxter, R. C. \& Cowell, C. T. (1987). Diurnal rhythm of growth hormone-independent binding protein for insulin-like growth factors in human plasma. Journal of Clinical Endocrinology and Metabolism 65, 432-440.

Baxter, R. C. \& Martin, J. L. (1989). Binding proteins for the insulin-like growth factors: structure, regulation and function. Progress in Growth Factor Research 1, 49-68. 
Busby, W. H., Hossenlopp, P., Binoux, M. \& Clemmons, D. R. (1989). Purified preparations of the amniotic fluidderived insulin-like growth factor-binding protein contain multimeric forms that are biologically active. Endocrinology 125, 773-777.

Busby, W. H., Snyder, D. K. \& Clemmons, D. R. (1988). Radioimmunoassay of a 26,000-dalton plasma insulinlike growth factor-binding protein: control by nutritional variables. Journal of Clinical Endocrinology and Metabolism 67, 1225-1230.

Clemmons, D. R. \& Underwood, L. E. (1991). Nutritional regulation of IGF-I and IGF binding proteins. Annual Review of Nutrition 11, 393-412.

Cotterill, A. M., Cowell, C. T., Baxter, R. C., McNeil, D. \& Silinik, M. (1988). Regulation of the growth hormone-independent growth-factor-binding protein in children. Journal of Clinical Endocrinology and Metabolism 67, 882-887.

Daughaday, W. H., Mariz, I. K. \& Blethen, S. L. (1980). Inhibition of access of bound somatomedin to membrane receptor and immunobinding sites: a comparison of radioreceptor and radioimmunoassay of somatomedin in native and acid-ethanol-extracted serum. Journal of Clinical Endocrinology and Metabolism 51, 781-788.

DeMellow, J. S. M. \& Baxter, R. C. (1988). Growth hormone-dependent insulin-like growth factor (IGF) binding protein both inhibits and potentiates IGF-I-stimulated DNA synthesis in human skin fibroblasts. Biochemical and Biophysical Research Communications 156, 199-204.

Elgin, R. G., Busby, W. H. Jr \& Clemmons, D. R. (1987). An insulin-like growth factor (IGF) binding protein enhances the biologic response to IGF-I. Proceedings of the National Academy of Sciences, USA 84, 3254-3258.

Kaufmann, U., Zapf, J. \& Froesch, E. R. (1978). Growth hormone dependence of non-suppressible insulin-like activity (NSILA) and of NSILA-carrier protein in rats. Acta Endocrinologica 87, 716-727.

Knauer, D. J. \& Smith, G. L. (1980). Inhibition of biological activity of multiplication-stimulating activity by binding to its carrier protein. Proceedings of the National Academy of Sciences, USA 77, 7252-7256.

Miura, Y., Kato, H. \& Noguchi, T. (1992). Effect of dietary proteins on insulin-like growth factor-1 (IGF-1) messenger ribonucleic acid content in rat liver. British Journal of Nutrition 67, 257-265.

Murphy, L. J., Seneviratne, C., Ballejot, G., Croze, F. \& Kennedy, T. G. (1990). Identification and characterization of a rat decidual insulin-like growth factor-binding protein complementary DNA. Molecular Endocrinology 4, 329-336.

Murphy, L. J., Seneviratne, C., Moreira, P. \& Reid, R. E. (1991). Enhanced expression of insulin-like growth factor-binding protein-1 in the fasted rat: the effects of insulin and growth hormone administration. Endocrinology 128, 689-696.

Ooi, G. T., Orlowski, C. C., Brown, A. L., Becker, R. E., Unterman, T. G. \& Rechler, M. M. (1990). Different tissue distribution and hormonal regulation of messenger RNAs encoding rat insulin-like growth factor-binding proteins-1 and -2. Molecular Endocrinology 4, 321-328.

Puissant, C. \& Houdebine, L.-M. (1990). An improvement of the single-step method of RNA isolation by acid guanidinium thiocyanate-phenol-chloroform extraction. BioTechniques 8, 148-149.

Ritvos, O., Ranta, T., Jalkanen, J., Suikkari, A. M., Voutilainen, R., Bohn, H. \& Rutanen, E. M. (1988). Insulinlike growth factor (IGF) binding protein from human decidua inhibits the binding and biological action of IGF$\mathrm{I}$ in cultured choriocarcinoma cells. Endocrinology 122, 2150-2157.

Rosen, K. M., Lamperti, E. D. \& Villa-Komaroff, L. (1990). Optimizing the Northern biot procedure. BioTechniques 8, 398-403.

Sakuma, K., Ohyaman, T., Sogawa, K., Fujii-Kuriyama, Y. \& Matsumura, Y. (1987). Low protein-high energy diet induces repressed transcription of albumin mRNA in rat liver. Journal of Nutrition 117, 1141-1148.

Snedecor, G. W. \& Cochran, W. G. (1967). One-way classifications. Analysis of variance. Inspection of all differences between pairs of means. In Statistical Methods, 6th ed., pp. 271-273. Ames, Iowa: Iowa State University Press.

Straus, D. S. \& Takemoto, C. D. (1990). Effect of dietary protein deprivation on insulin-like growth factor (IGF)I and -II, IGF binding protein-2, and serum albumin gene expression in rat. Endocrinology 127, 1849-1860.

Takahashi, S., Kajikawa, M., Umezawa, T., Takahashi, S.-I., Kato, H., Miura, Y., Nam, T. J., Noguchi, T. \& Naito, H. (1990). Effect of dietary proteins on the plasma immunoreactive insulin-like growth factor1 /somatomedin C concentration in the rat. British Journal of Nutrition 63, 521-534.

Takenaka, A., Miura, Y., Mori, M., Hirosawa, M., Kato, H. \& Noguchi, T. (1991). Distribution of messenger RNAs of insulin-like growth factor (IGF)-binding proteins- 1 and -3 between parenchymal and nonparenchymal cells in rat liver. Agricultural and Biological Chemistry 55, 1191-1193.

Takenaka, A., Ohishi, Y., Noguchi, T. \& Naito, H. (1989). Effect of some essential amino acid deficiency in the medium on the action of insulin on primary cultured hepatocytes of rats. Hepatocytes do not respond to insulin in some essential amino acid-deficient medium. International Journal of Biochemistry 21, 1255-1263.

Umezawa, T., Ohsawa, Y., Miura, Y., Kato, H. \& Noguchi, T. (1991). Effect of protein deprivation on insulinlike growth factor-binding proteins in rats. British Journal of Nutrition 66, 105-116.

Waterlow, J. C., Garlick, P. J. \& Millward, D. J. (1978). The effects of nutrition and hormones on protein turnover in the liver. In Protein Turnover in Mammalian Tissues and in the Whole Body, pp. 718-723. Amsterdam, New York, Oxford: North-Holland. 